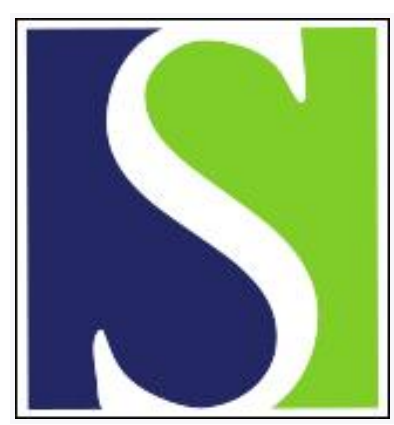

Scand J Work Environ Health 1991;17(3):149-158

https://doi.org/10.5271/sjweh.1716

Issue date: Jun 1991

Effects of low-frequency magnetic fields on embryonic development and pregnancy.

by Juutilainen J

Affiliation: Department of Environmental Sciences, University of Kuopio, Finland.

This article in PubMed: www.ncbi.nlm.nih.gov/pubmed/2068553

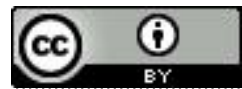




\title{
Effects of low-frequency magnetic fields on embryonic development and pregnancy
}

\author{
by Jukka Juutilainen, PhD
}

\begin{abstract}
JUUTILAINEN J. Effects of low-frequency magnetic fields on embryonic development and pregnancy. Scand J Work Environ Health 1991;17:149-58. Experimental and epidemiologic studies on the effects of low-frequency magnetic fields on pregnancy are reviewed. The literature suggests that these fields have adverse effects on chick embryo development. The interaction mechanism is not known. The results of experiments with mammals are inconsistent. There is more evidence of effects on mice than on rats, and the data suggest that fetal loss might be increased rather than malformations. Most of the epidemiologic studies related to pregnancy and low-frequency magnetic fields have concerned operators of a video display terminal (VDT). The results do not provide evidence for an association between adverse pregnancy outcome and use of a VDT. Other (stronger) sources of low-frequency magnetic fields have been addressed in only a few studies. It is not yet possible to conclude whether occupational or residential exposure to low-frequency magnetic fields affects human prenatal development. There is an apparent need for further investigation.
\end{abstract}

Key terms: electromagnetic fields, epidemiology, fetal loss, malformations, teratology.

The people of industrialized societies are continuously exposed to low-frequency magnetic fields produced by various electrical installations and appliances. The strongest fields are found at workplaces close to high power conductors and electrical equipment. It is well known that very strong magnetic fields $(>10 \mathrm{mT}$ at $50-60 \mathrm{~Hz}$ ) are harmful, but it is unclear whether the moderate intensities $(1 \mu \mathrm{T}-1 \mathrm{mT})$ occurring in residential and occupational environments threaten human health $(1-5)$.

The recent discussion on the health risks of lowfrequency magnetic fields focuses on cancer and adverse pregnancy outcome. Several reviews are available about the possible association between cancer and occupational or residential exposure to low-frequency fields (6-9).

This review presents an evaluation of the experimental and epidemiologic studies on the possible effects of low-frequency magnetic fields on embryonic development and pregnancy.

\section{Electric and magnetic fields}

All conductors carrying electric current are surrounded by electric and magnetic fields. The strength of a mag-

\footnotetext{
1 Department of Environmental Sciences, University of Kuopio, Finland.
}

Reprint requests to: Dr J Juutilainen, Department of Environmental Sciences, University of Kuopio, PO Box 6, SF-70211 Kuopio, Finland. netic field is proportional to current flowing in the conductor, whereas that of a electric field is proportional to voltage. Both fields decrease as distance increases.

The intensity of a magnetic field may be described by two quantities, the magnetic field strength (in amperes/meter) or the magnetic flux density (in teslas). One ampere per meter corresponds to $1.257 \mu \mathrm{T}$ in air. A non-SI unit called gauss $\left(1 \mathrm{G}=10^{-4} \mathrm{~T}\right)$ is still often used in the United States.

In contrast to the static magnetic field of the earth, magnetic fields produced by alternating current are time varying. The number of oscillations per second of a time-varying electric or magnetic field is called frequency and is given in hertz. Low-frequency fields include two frequency ranges called extremely low frequency $(0-300 \mathrm{~Hz})$ and very low frequency $(0.3-$ $100 \mathrm{kHz}$ ). The most common frequencies of extremely low-frequency fields in the environment are 50 and $60 \mathrm{~Hz}$, since these frequencies are used in the transmission of electricity. Waveform is a variable used to describe the dependence on time of time-varying fields. The 50 - or $60-\mathrm{Hz}$ fields around electric wires and appliances have sinusoidal waveform. Fields with triangular waveforms are found around video display terminals.

The natural background of $50-\mathrm{Hz}$ magnetic fields is about $10^{-6} \mathrm{~A} / \mathrm{m}$ (1). In residences and offices the field strength is usually below $0.1 \mathrm{~A} / \mathrm{m}$, but local "hot spots" with higher values are occasionally found. Lowfrequency magnetic fields under powerlines are about 1 to $10 \mathrm{~A} / \mathrm{m}$, while fields up to about $10^{-4} \mathrm{~A} / \mathrm{m}$ can be measured at some industrial workplaces close to, eg, induction heaters, welding equipment, and electric motors. 


\section{Studies using nonmammalian models}

Delgado and his co-workers (10) reported that pulsed magnetic fields at frequencies of 10,100 , and $1000 \mathrm{~Hz}$ strongly increased the percentage of abnormalities in chick embryos incubated for $2 \mathrm{~d}$. Pulses with a duration of $0.5 \mathrm{~ms}$ and peak flux densities of $0.12,1.2$, or $12 \mu \mathrm{T}$ were used. In later experiments by the same research group, the teratogenic effect seemed to depend on the waveform used (11). It was, however, later reported that the determination of the waveform was incorrect (12) and that there were uncontrolled highfrequency oscillations in the exposure system (13).

In further experiments the effect of pulsed magnetic fields seemed to depend on the orientation of the chick embryo in relation to the geomagnetic field (14). In the experiments of Leal et al (15) the effect of $100-\mathrm{Hz}$, $0.4-$ or $1-\mu \mathrm{T}$ pulsed fields on chick embryos was not always reproducible. In the combined data of $13 \mathrm{ex}-$ periments ( $40-50$ eggs per experiment), $35 \%$ of the exposed and $30 \%$ of the control embryos were abnormal. However, there was a significant correlation between the variations in the results and very small time-dependent changes in the local geomagnetic field. This finding was interpreted by the authors as suggesting that the effect might occur only at some precise values of the geomagnetic field.

The experiments by Martin (16) suggest that pulsed magnetic fields affect chick embryo development only during a short critical period at the beginning of incubation. A significant increase in abnormalities was observed only when the embryos were exposed during the first $24 \mathrm{~h}$ of incubation.

In the experiments of my co-workers and I (17), the percentage of abnormalities was increased in chick embryos exposed during their first $2 \mathrm{~d}$ of development to $100-\mathrm{Hz}$ magnetic fields with sinusoidal, rectangular, and pulsed waveforms. In another series of experiments with sinusoidal waveform, similar effects were found in a wide range of frequencies (18). The effects of $100-\mathrm{Hz}$ sinusoidal fields with a field strength of $1 \mathrm{~A} / \mathrm{m}$ were confirmed in experiments with a large number of eggs (19). Further experiments with $50 \mathrm{~Hz}$ confirmed that there is an effect at this frequency, too, and suggested that the field strength-response curve has a sharp threshold at $1 \mathrm{~A} / \mathrm{m}(20)$.

In two studies, the results of Delgado et al (10) could not be replicated $(21,22)$, and no effects were found in chick embryos exposed to $20-\mathrm{kHz}$ magnetic fields with triangular waveform (23). Exposure of chick and quail eggs to a $50-\mathrm{Hz}, 500-\mu \mathrm{T}$ sinusoidal magnetic field during the first 4 or $7 \mathrm{~d}$ of incubation did not increase the percentage of dead or abnormal embryos (24).

In one study, an increased proportion of abnormal embryos was observed in all three separate egg groups exposed to pulsed magnetic fields, but the differences from the corresponding control groups did not reach statistical significance when the experiments were analyzed separately (25). No statistical analysis of the combined data was performed.

A large well-designed international study aimed at replicating Delgado's (10) results has been carried out in six separate laboratories (26). Identical equipment and standardized experimental procedures were used. The eggs, however, came from different sources, and the local geomagnetic fields were different. The combined data showed a significant $(\mathrm{P}<0.001)$ increase of abnormal embryos in the exposed group. There were, however, significant differences in the results from the six laboratories that suggested the involvement of unknown environmental or biological variables.

There are thus both positive and negative findings in the studies on the effects of low-frequency magnetic fields on chick embryo development. Furthermore, the positive findings are not consistent as to the lowest field strength causing abnormal development. In some studies the field strength is given as the time-

Table 1. Comparison of some studies on the effects of low-frequency magnetic fields on chick embryos. (MF = magnetic field, $\mathrm{NR}=$ not reported, vert $=$ vertical, horiz $=$ horizontal)

\begin{tabular}{|c|c|c|c|c|c|c|c|c|c|c|c|c|c|}
\hline Reference & $\begin{array}{l}\text { Wave- } \\
\text { form }\end{array}$ & $\begin{array}{c}\text { Fre- } \\
\text { quency } \\
(\mathrm{Hz})\end{array}$ & $\begin{array}{c}\text { Peak } \\
\text { field } \\
\text { strength } \\
(\mathrm{A} / \mathrm{m})\end{array}$ & $\begin{array}{c}\text { Tem- } \\
\text { perature } \\
\left({ }^{\circ} \mathrm{C}\right)\end{array}$ & $\begin{array}{c}\text { Rela- } \\
\text { tive } \\
\text { humi- } \\
\text { dity } \\
(\%)\end{array}$ & $\begin{array}{l}\text { Dura- } \\
\text { tion of } \\
\text { storage } \\
\text { of the } \\
\text { eggs }\end{array}$ & $\begin{array}{l}\text { Vibra- } \\
\text { tion } \\
\left(\mathrm{m} / \mathrm{s}^{2}\right)\end{array}$ & $\begin{array}{l}\text { Low } \\
\text { fre- } \\
\text { quency } \\
\text { MF at } \\
\text { control } \\
\text { eggs } \\
(\mathrm{A} / \mathrm{m})\end{array}$ & $\begin{array}{c}\text { Geo- } \\
\text { magnetic } \\
\text { field } \\
(\mu \mathrm{T})\end{array}$ & $\begin{array}{l}\text { Orientation } \\
\text { of the eggs }\end{array}$ & $\begin{array}{l}\text { Direction } \\
\text { of the field }\end{array}$ & $\begin{array}{l}\text { Exis- } \\
\text { tence } \\
\text { of sig- } \\
\text { nificant } \\
\text { effects }\end{array}$ & $\begin{array}{c}\text { Weakest } \\
\text { effective } \\
\text { field } \\
(\mathrm{A} / \mathrm{m})\end{array}$ \\
\hline $\begin{array}{l}\text { Delgado } \\
\text { et al (10) }\end{array}$ & $\begin{array}{l}0.5 \mathrm{~ms} \\
\text { pulses }\end{array}$ & $10-1 \mathrm{k}$ & $0.095-9.5$ & 38 & 55 & NR & NR & NR & NR & Horizontal & Horizontal & Yes & 0.095 peak \\
\hline $\begin{array}{l}\text { Maffeo et al } \\
\text { (21) }\end{array}$ & $\begin{array}{l}0.5 \mathrm{~ms} \\
\text { pulses }\end{array}$ & $100-1 k$ & $0.095-9.5$ & 38 & 80 & NR & NA & 0.2 & NR & Horizontal & Vertical & No & . \\
\hline $\begin{array}{l}\text { Sandström } \\
\text { et al (23) }\end{array}$ & $\begin{array}{l}\text { Tri- } \\
\text { angular }\end{array}$ & $20 \mathrm{k}$ & $0.08-13$ & 38 & 75 & $1 \mathrm{~d}$ & NR & NR & NR & Horizontal & Horizontal & No & . \\
\hline $\begin{array}{l}\text { Martin } \\
(16)\end{array}$ & $\begin{array}{l}0.5 \mathrm{~ms} \\
\text { pulses }\end{array}$ & 100 & 0.95 & 37.8 & 75 & NR & NR & NR & $\begin{array}{l}33-36 \text { vert } \\
17-23 \text { horiz }\end{array}$ & Horizontal & Horizontal & Yes & 0.95 peak \\
\hline \multirow[t]{3}{*}{$\begin{array}{l}\text { Juutilainen } \\
\text { et al (17) }\end{array}$} & $\begin{array}{l}0.5 \mathrm{~ms} \\
\text { puises }\end{array}$ & 100 & $2-800$ & & & & & & & & & & $\begin{array}{l}1.6 \mathrm{rms} \\
=17 \text { peak }\end{array}$ \\
\hline & & & & $37-38$ & 55 & $<4 d<$ & $<3 \times 10^{-2}$ & $2<0.02$ & $\begin{array}{l}33-38 \text { vert } \\
12-14 \text { horiz }\end{array}$ & Vertical & Vertical & Yes & \\
\hline & sine & 100 & $0.28-230$ & & & & & & & & & & $\begin{array}{l}1 \mathrm{rms} \\
=2.8 \text { peak }\end{array}$ \\
\hline
\end{tabular}


average, or root mean square (rms), field strength, whereas the instantaneous peak value is given by other researchers. In our experiments (17) with the $0.5-\mathrm{ms}$ pulses similar to those used by Delgado (10), no effect was observed at $0.2 \mathrm{~A} / \mathrm{m}$ rms. The weakest field that produced effects was $1.6 \mathrm{~A} / \mathrm{m} \mathrm{rms}$, corresponding to a peak field strength of $17 \mathrm{~A} / \mathrm{m}$. In the experiments of the Delgado group $(10,11)$ and Martin $(16)$, effects on embryonal development were observed at peak fields as weak as $0.12 \mu \mathrm{T}(0.095 \mathrm{~A} / \mathrm{m})$ and 1.2 $\mu \mathrm{T}(0.95 \mathrm{~A} / \mathrm{m})$.

There are several possible explanations for the inconsistent results. The exposure conditions were not similar (table 1). The results obtained in our laboratory (19) demonstrate the importance of incubation temperature and duration of egg storage before incubation. High temperature and long storage increase the percentage of abnormalities in the control embryos, and thus the probability of finding a statistically significant difference between the exposed and control eggs is decreased. The same is true for other factors that increase the percentage of abnormal controls, eg, a high level of mechanical vibration at the location of the control eggs.

In studies of this kind it is important that the lowfrequency magnetic field exposure of the control eggs be as low as possible. Unfortunately, the field strength at the location of the controls $(50-60 \mathrm{~Hz}$ background and leakage from the exposure facility) has not been measured in all studies.

The orientation of the eggs and of the magnetic field was different in the various studies, and therefore caused different induced currents in relation to the embryo (23). The embryo is usually located at the top of the yolk with its head-tail axis perpendicular to the long axis of the egg. Thus, in the experiments where horizontal fields were used $(10,11,16,23)$, the induced currents flowed along the head-tail axis of the embryo, whereas the currents induced by the vertical fields used in some experiments $(17-22)$ circle around the embryo.

The geomagnetic field has probably been different in the various studies. This variation may explain some of the inconsistencies in the results if the biological effects of low-frequency magnetic fields are based on resonance interaction mechanisms requiring given relationships between static and alternating magnetic fields (27).

There are also differences in the eggs used in various experiments. Eggs from White Leghorn have been used in most of the experiments. The White Leghorn, however, is a poorly defined strain consisting of several local varieties. The environmental conditions and feeding of the hens have also probably been different in different studies.

The available data suggest that low-frequency magnetic fields disturb the development of chick embryos, at least under some conditions. Further experiments are necessary to understand the environmental and biological factors that modify the response of the embryos.

Low-frequency magnetic fields have also been reported to retard the development of fish embryos at $60 \mathrm{~Hz}, 100 \mu \mathrm{T}(28)$ and to induce morphological changes in the pineal organ of chick embryos at $60 \mathrm{~Hz}$, $80 \mu \mathrm{T}$ (29). The pulsed magnetic waveform used clinically in bone healing (peak intensity $2 \mathrm{mT}$ ) has been reported to accelerate the embryonal development of sea urchins (30). A $60-\mathrm{Hz}$ magnetic field at $100 \mu \mathrm{T}$, however, caused a developmental delay in sea urchin embryos (31). Teratogenic effects in toad embryos were observed after exposure to $20-\mathrm{Hz}, 2-\mathrm{kHz}$, or $20-\mathrm{kHz}$ magnetic fields at $10-15 \mathrm{mT}(32)$. Oviposition and mortality during the development of Drosophila flies were affected by exposure to pulsed $100-\mathrm{Hz}(1.8 \mathrm{mT})$ and sinusoidal $50-\mathrm{Hz}(1 \mathrm{mT})$ magnetic fields (33).

\section{Studies on mammals}

Zecca and his co-workers (34) exposed 10 pregnant Sprague-Dawley rats to a $50-\mathrm{Hz}$ magnetic field at $5.8 \mathrm{mT}$. No malformations were observed. The number of resorptions and dead fetuses was higher in the exposed than in the control group, but the number of animals used was too small for any conclusions. In the experiments of Rivas et al (35), 25 to 27 pregnant Swiss mice per group were exposed to $50-\mathrm{Hz}$ pulsed magnetic fields at $2.3 \mathrm{mT}$ or $83 \mu \mathrm{T}$. The number of live births per litter and the mean birth weight were slightly lower among the exposed animals, but the differences from the controls were not statistically significant.

Two Swedish groups have found that low-frequency magnetic fields affect the fetal development of mice. The findings of these two studies are, however, inconsistent in respect to the type of effects observed. Tribukait et al (36) exposed $\mathrm{C} 3 \mathrm{H}$ mice to $100-\mathrm{Hz}$ rectangular pulses and to $20-\mathrm{kHz}$ fields with triangular (sawtooth) waveform at peak flux densities of 1 and $15 \mu \mathrm{T}$. The $20-\mathrm{kHz}$ field was used because these kinds of fields are found around video display terminals. The number of fetuses with external malformations was increased in the groups exposed to the $20-\mathrm{kHz}$ field. In the experiments of Frölen \& Svedenstål $(37,38)$ a large number of CBA mice was exposed to a magnetic field with a frequency of $20 \mathrm{kHz}$ and a peak flux density of $15 \mu \mathrm{T}$. No differences in the number of malformations were found, but the number of resorptions (fetal losses) in the exposed groups was about twice as high as in the control groups. This difference was statistically highly significant.

A significant increase of minor skeletal anomalies in the highest exposure group $(66 \mu \mathrm{T})$ was observed when pregnant Sprague-Dawley rats were exposed to $18-\mathrm{kHz}$ magnetic fields with a triangular waveform (39). The number of malformations and resorptions was low and not related to magnetic field exposure. 
No dead fetuses were found. The authors discounted the increased skeletal anomalies as common "noise" that appears in every teratological evaluation.

Similar results were obtained in another study on rats (40). The proportions of malformations or resorptions were not increased in Han:Wistar rats exposed to $20-\mathrm{kHz}$ sawtooth or $50-\mathrm{Hz}$ sinusoidal magnetic fields. The intensities were $12 \mathrm{~A} / \mathrm{m}(15 \mu \mathrm{T})$ peak-topeak at $20 \mathrm{kHz}$ and $10 \mathrm{~A} / \mathrm{m}(12.6 \mu \mathrm{T}) \mathrm{rms}$ at $50 \mathrm{~Hz}$. The proportion of fetuses with minor skeleton anomalies was significantly increased in both exposed groups. The skeleton anomalies observed were mild and probably not detrimental for later normal development.

No significant effects on prenatal development were reported in recent studies on Sprague-Dawley rats exposed to $60-\mathrm{Hz}, 1-\mu \mathrm{T}$ or $1-\mathrm{mT}$ fields $(41)$, or in CD-1 mice exposed to $20-\mathrm{kHz}$ sawtooth fields at 0.33 to 16.7 $\mu \mathrm{T}$ (42). When pregnant Sprague-Dawley rats were exposed to $15-\mathrm{Hz}$ fields at $0.8 \mathrm{mT}$ for $15 \mathrm{~min}$ twice a day from day 15 through day 20 of gestation, the male offspring exhibited significantly less scent-marking behavior than controls. Accessory sex organ weights were also significantly higher among the exposed animals (43).

In a Swedish study (44), cows were kept under a $400-\mathrm{kV}$ transmission line for $120 \mathrm{~d}$. The average electric field strength was about $4 \mathrm{kV} / \mathrm{m}$, and the magnetic flux density was about $2 \mu \mathrm{T}$. The reproductive parameters studied were length and regularity of ovulation intervals, midcycle plasma progesterone level, intensity of estrous signs, number of inseminations per pregnancy, percentage of pregnant animals, and proportion of fetuses showing heart activity after the slaughter of the dam. For none of these parameters were there differences in comparison with the control animals.

There is no consistent pattern in the effects reported in different investigations. In one study (38), exposure to low-frequency magnetic fields seemed to increase the number of resorptions, while slightly increased frequencies of malformations (36) or minor skeletal anomalies $(39,40)$ were observed in other studies (table 2). Furthermore, no significant effects were found in some studies in spite of a large study sample $(41,42)$. There are two alternatives with which to interpret these inconsistencies. First, it is possible that the statistically significant differences observed in some studies are due to chance and that they reflect no real effect of low-frequency magnetic fields. The other possibility is that low-frequency magnetic fields affect intrauterine development, but the results vary because of differences in the experimental conditions. The use of different experimental animals may have caused the differences in the results. It is common in teratological evaluations that a certain strain may respond to, eg, a given chemical substance, while no effects are found in another species or another strain of the same species. It is also usual that skeleton is affected in rats, while mice easily get visceral malformations (45).

As discussed in connection with the chick embryo studies, differences in the local geomagnetic fields may have affected the results. The studies also differ in the field strengths, frequencies and waveforms used. The low-frequency magnetic field strength at the location of the control animals has been reported in only two studies.

There are also differences in the statistical methods used in different studies. In teratologic literature, there has been discussion on whether litter or fetus should be used as the basic unit in statistical analysis (eg, in reference 46). Fetus-based analysis may be misleading since the response of a fetus is not always independent of other fetuses of the same litter. If such "litter effects" occur, statistical tests requiring independence of the basic sampling units are invalid. On the other hand, analyses based on the proportion of affected litters are insensitive in detecting small differences. The "per litter" approach based on the proportion of af-

Table 2. Studies on the effects of low-frequency magnetic fields on rodents. $(\mathrm{SD}=$ Sprague-Dawley, $\mathrm{C}=\mathrm{control}$ )

\begin{tabular}{|c|c|c|c|c|c|c|c|c|c|c|c|c|}
\hline Reference & $\begin{array}{l}\text { Animal } \\
\text { species } \\
\text { and strain }\end{array}$ & $\begin{array}{c}\text { Fre- } \\
\text { quency } \\
(\mathrm{Hz})\end{array}$ & Waveform & $\begin{array}{l}\text { Field } \\
\text { strength } \\
(\mathrm{A} / \mathrm{m})\end{array}$ & $\begin{array}{l}\text { Exposure } \\
\text { schedule }\end{array}$ & $\begin{array}{l}\text { Litters } \\
(\mathrm{N})\end{array}$ & $\begin{array}{l}\text { Fetuses } \\
\text { (N) }\end{array}$ & $\begin{array}{l}\text { Implan- } \\
\text { tations } \\
\text { per } \\
\text { litter }\end{array}$ & $\begin{array}{c}\text { Resorp- } \\
\text { tions } \\
(\%)\end{array}$ & $\begin{array}{l}\text { Malfor- } \\
\text { mations } \\
(\%)\end{array}$ & $\begin{array}{l}\text { Minor } \\
\text { visceral } \\
\text { anom- } \\
\text { alies } \\
(\%)\end{array}$ & $\begin{array}{l}\text { Minor } \\
\text { skeleton } \\
\text { anom- } \\
\text { alies } \\
(\%)\end{array}$ \\
\hline$\underset{(34)}{\text { Zecca et al }}$ & SD rat & 50 & . & $\begin{array}{r}C \\
4600\end{array}$ & $\begin{array}{l}3 \mathrm{~h} / \mathrm{d} \\
\text { days } 6-15\end{array}$ & $\begin{array}{l}10 \\
10\end{array}$ & $\begin{array}{l}113 \\
110\end{array}$ & $\begin{array}{l}11.9 \\
12.1\end{array}$ & $\begin{array}{l}5.3 \\
10^{-3}\end{array}$ & $\begin{array}{l}0 \\
0\end{array}$ & $\begin{array}{l}0 \\
0\end{array}$ & $\begin{array}{l}\cdots \\
\cdots\end{array}$ \\
\hline $\begin{array}{l}\text { Stuchly et al } \\
\text { (39) }\end{array}$ & SD rat & $18 k$ & Triangular & $\begin{array}{l}C \\
4.5 \\
18 \\
53\end{array}$ & $7 \mathrm{~h} / \mathrm{d}$ & $\begin{array}{l}20 \\
20 \\
20 \\
20\end{array}$ & $\begin{array}{l}262 \\
266 \\
248 \\
246\end{array}$ & $\begin{array}{l}13.3 \\
13.3 \\
12.4 \\
12.4\end{array}$ & $\begin{array}{l}1.1 \\
0 \\
0 \\
0\end{array}$ & $\begin{array}{l}0.4 \\
0.3 \\
0 \\
0.4\end{array}$ & $\begin{array}{l}0.4 \\
0.4 \\
1.2 \\
0.8\end{array}$ & $\begin{array}{l}6.9 \\
6.4 \\
10 \\
20\end{array}$ \\
\hline $\begin{array}{l}\text { Huuskonen et al } \\
(40)\end{array}$ & $\begin{array}{l}\text { Wistar } \\
\text { rat }\end{array}$ & $\begin{array}{l}50 \\
20 k\end{array}$ & $\begin{array}{l}\text { Sinusoidal } \\
\text { Triangular }\end{array}$ & $\begin{array}{r}C \\
10 \\
12\end{array}$ & Continuous & $\begin{array}{l}58 \\
64 \\
64\end{array}$ & $\begin{array}{l}521 \\
663 \\
613\end{array}$ & $\begin{array}{r}9.6 \\
11.0 \\
10.2\end{array}$ & $\begin{array}{l}7.3 \\
6.2 \\
6.5\end{array}$ & $\begin{array}{l}0 \\
0 \\
0.2\end{array}$ & $\begin{array}{l}0.6 \\
0.7 \\
0.7\end{array}$ & $\begin{array}{l}13 \\
23 \\
21\end{array}$ \\
\hline $\begin{array}{ll}\text { Frölen \& } & \text { |a } \\
\text { Svedenstål } \\
(37)\end{array}$ & CBA mouse & $20 k$ & Triangular & $\begin{array}{r}C \\
12 \\
C \\
12\end{array}$ & Continuous & $\begin{array}{l}154 \\
211 \\
308 \\
396\end{array}$ & $\begin{array}{l}1124 \\
1566 \\
1962 \\
2459\end{array}$ & $\begin{array}{l}7.7 \\
8.3 \\
6.8 \\
7.0\end{array}$ & $\begin{array}{c}5.9 \\
12 \\
6.4 \\
12\end{array}$ & $\begin{array}{l}1.0 \\
1.3 \\
0.6 \\
0.9\end{array}$ & $\begin{array}{l}\cdots \\
\cdots \\
\cdots \\
\cdots\end{array}$ & $\begin{array}{l}\cdots \\
\cdots \\
\cdots \\
\cdots\end{array}$ \\
\hline $\begin{array}{l}\text { Tribukait et al } \\
\text { (36) }\end{array}$ & $\mathrm{C} 3 \mathrm{H}$ mouse & $\begin{array}{l}100 \\
20 k\end{array}$ & $\begin{array}{l}\text { Rectangular } \\
\text { Triangular }\end{array}$ & $\begin{array}{r}\mathrm{C} \\
12 \\
12\end{array}$ & Continuous & $\begin{array}{l}61 \\
35 \\
39\end{array}$ & $\begin{array}{l}297 \\
181 \\
211\end{array}$ & $\begin{array}{l}5.4 \\
5.6 \\
7.0\end{array}$ & $\begin{array}{r}9.1 \\
7.2 \\
10.4\end{array}$ & $\begin{array}{l}0.7 \\
1.7 \\
4.7\end{array}$ & $\begin{array}{l}\cdots \\
\cdots \\
\cdots\end{array}$ & $\begin{array}{l}\cdots \\
\cdots \\
\cdots\end{array}$ \\
\hline
\end{tabular}

a Data frọm two separate series of experiments by Frölen \& Svedestål are given. 
fected fetuses per litter (not on the proportion of affected litters) is often considered the most appropriate method of analysis. This method is valid also when litter effects occur, and it has been shown that there is only little loss in sensitivity compared with per fetus analysis (46). Unfortunately the "per litter" approach has not been used in the studies reviewed in this presentation. Only the percentage of affected fetuses was reported in the study on $\mathrm{C} 3 \mathrm{H}$ mice (36). The proportion of affected fetuses and the proportion of affected litters were given in two studies $(38,39)$. Only the fetusbased analysis gave significant results in the study on rats by Stuchly et al (39), while the increase of resorptions in CBA mice was significant in both analyses (38).

In some studies, the animals were exposed for $3 \mathrm{~h} / \mathrm{d}$ (35) or $7 \mathrm{~h} / \mathrm{d}$ (39), while the exposure was continuous in the others. In one experiment (35), the exposure was started on day 6 of gestation, while in the other studies the animals were exposed from the beginning of pregnancy. Svedenstål \& Frölen (38) varied the starting of the exposure between days 1 and 7 .

The sensitivity of mammalian embryos to harmful factors varies depending on the stage of development. During the preimplantation period, exposure to harmful agents will not usually cause teratogenic effects. A more probable result is reduced viability (a decrease in implantations or an increase in early deaths of the embryos). After implantation, during the period of early differentiation and organogenesis, the embryo is highly susceptible to teratogenesis. It then becomes increasingly resistant with increasing age. The increase in resorptions observed in CBA mice (38) suggests that low-frequency magnetic field exposure might affect the early stages of development.

Svedenstål \& Frölen tried to test the hypothesis that early development is the most sensitive period by varying the time from the onset of pregnancy to the beginning of the exposure to low-frequency magnetic fields. When the exposure was started on days 1, 2, or 5 of gestation, the percentage of resorptions was significantly higher in the exposed than in the control animals. When the exposure was postponed to the 7 th day after conception, however, the frequency of resorptions was similar for the exposed and control mice (38).

If one considers the results of all teratological investigations with mammals, it is evident that lowfrequency magnetic fields are not highly teratogenic or embryotoxic. In one study, the proportion of malformed fetuses was about $3 \%$, while in other studies it was not more than $1 \%$. The highest proportion of resorptions reported was $12 \%$ of fetuses. Subtle effects cannot be ruled out, however. Malformations and resorptions are more likely to occur in mice than in rats. Especially the very large amount of data produced by Frölen and Svedenstål $(37,38)$ is strongly indicative of effects on CBA mice. The results suggest that, at least in CBA mice, sensitivity to magnetic fields is highest during the early stages of development.

\section{Epidemiologic studies}

There has been much discussion about the possible adverse effects of video display terminals on pregnancy outcome. (See, eg, reference 47.) Video display terminals with a cathode ray tube display emit extremely low-frequency magnetic fields at 50 or $60 \mathrm{~Hz}$ and very low-frequency magnetic fields at $15-30 \mathrm{kHz}$. The strength of the extremely low-frequency magnetic field is a few amperes per meter (a few microteslas) at the surface of the terminal and about $0.1-0.3 \mathrm{~A} / \mathrm{m}(0.1-$ $0.4 \mu \mathrm{T})$ at the operator's position $(48,49)$. In addition to low-frequency magnetic fields, video display terminals emit several other types of electromagnetic energy, including optical radiation, radiofrequency radiation, and static electric fields. The intensity of the emissions is very low compared with existing exposure limits.

The public concerns about the effects of video display terminals on pregnancy are based on reported small clusters of miscarriages and birth defects among operators. The systematic epidemiologic studies carried out, however, do not support the view that the terminals are dangerous to use during pregnancy (table 3 ). Risks slightly above 1.0 have been observed in some studies, especially in the most heavily exposed groups $(50-52)$. However, since the use of these terminals was self-reported in these studies, the increased risk estimates might be explained by recall bias (cases reporting use more often than referents). The importance and magnitude of recall bias is not known, and it may vary between different studies. Some authors $(52,53)$, but not all $(50)$, have found evidence for recall bias in their data. No increased risks were observed when exposure was assessed by means not affected by recall bias $(54,55)$. The results of a recent case-base study did not support an association between the use of video display terminals and congenital malformations (56) or spontaneous abortion (57).

In the case-referent study of Tikkanen et al (58) the adjusted risk estimate of cardiovascular malformations was 1.9 among the offspring of mothers using video display terminals for more than $4 \mathrm{~h}$ a week, but the confidence interval (CI) was wide (95\% CI 0.7-5.0). All the six chromosome anomalies included in the cases were in the high-exposure group. The risk estimate for cardiovascular malformation without chromosome anomalies was 1.4 (95\% CI 0.5-3.8).

The magnetic field emissions of video display terminals are relatively weak. The pregnancy outcome of women exposed to other sources of low-frequency magnetic fields has been investigated in only a few studies.

An association between fetal development and the use of electric blankets and heated waterbeds was reported by Wertheimer \& Leeper (59). These appli- 
Table 3. Epidemiologic studies on video display terminals and pregnancy outcome. ( $95 \% \mathrm{Cl}=95 \%$ confidence interval)

\begin{tabular}{|c|c|c|c|c|c|c|c|}
\hline Reference & $\begin{array}{l}\text { Study } \\
\text { design }\end{array}$ & $\begin{array}{l}\text { Exposure } \\
\text { assessment }\end{array}$ & End point & Exposure & $\begin{array}{l}\text { Cases } \\
(\mathrm{N})\end{array}$ & $\begin{array}{c}\text { Risk } \\
\text { estimate }\end{array}$ & $95 \% \mathrm{Cl}$ \\
\hline $\begin{array}{l}\text { Kurppa et al } \\
\text { (55) }\end{array}$ & $\begin{array}{l}\text { Case- } \\
\text { referent }\end{array}$ & $\begin{array}{l}\text { Estimate by } \\
\text { researchers }^{\mathrm{a}}\end{array}$ & $\begin{array}{l}\text { Birth } \\
\text { defect }\end{array}$ & $\begin{array}{l}\text { Any } \\
>4 \mathrm{~h} / \text { week }\end{array}$ & $\begin{array}{l}51 \\
31\end{array}$ & $\begin{array}{l}0.9 \\
1.0\end{array}$ & $\begin{array}{l}0.6-1.2 \\
0.6-1.6\end{array}$ \\
\hline \multirow[t]{2}{*}{$\begin{array}{l}\text { Ericson \& } \\
\text { Källen (51) }\end{array}$} & \multirow[t]{2}{*}{$\begin{array}{l}\text { Case- } \\
\text { referent }\end{array}$} & \multirow[t]{2}{*}{$\begin{array}{l}\text { Self- } \\
\text { reported }\end{array}$} & $\begin{array}{l}\text { Spontaneous } \\
\text { abortion }\end{array}$ & $\begin{array}{l}\text { Any } \\
>10 \mathrm{~h} / \text { week } \\
>20 \mathrm{~h} / \text { week }\end{array}$ & $\begin{array}{r}200 \\
117 \\
73\end{array}$ & $\begin{array}{l}1.1 \\
1.2 \\
1.2\end{array}$ & $\begin{array}{l}0.9-1.4 \\
0.9-1.7 \\
0.9-1.7\end{array}$ \\
\hline & & & $\begin{array}{l}\text { Birth } \\
\text { defect }\end{array}$ & $\begin{array}{l}\text { Any } \\
>10 \mathrm{~h} / \text { week } \\
>20 \mathrm{~h} / \text { week }\end{array}$ & $\begin{array}{l}72 \\
44 \\
32\end{array}$ & $\begin{array}{l}1.7 \\
2.0 \\
2.3\end{array}$ & $\begin{array}{l}1.1-2.6 \\
1.2-3.2 \\
1.4-3.9\end{array}$ \\
\hline \multirow[t]{2}{*}{$\begin{array}{l}\text { Ericson \& } \\
\text { Källen (54) }\end{array}$} & \multirow[t]{2}{*}{ Cohort } & \multirow[t]{2}{*}{$\begin{array}{l}\text { Job clas- } \\
\text { sification }\end{array}$} & $\begin{array}{l}\text { "Significant" } \\
\text { malformation }\end{array}$ & $\begin{array}{l}\text { Low } \\
\text { Medium } \\
\text { High }\end{array}$ & $\begin{array}{l}48 \\
25 \\
67\end{array}$ & $\begin{array}{l}0.9 \\
0.8 \\
0.9\end{array}$ & $\begin{array}{l}0.6-1.1 \\
0.5-1.1 \\
0.7-1.2\end{array}$ \\
\hline & & & $\begin{array}{l}\text { Spontaneous } \\
\text { abortion }\end{array}$ & $\begin{array}{l}\text { Low } \\
\text { Medium } \\
\text { High }\end{array}$ & $\begin{array}{r}137 \\
56 \\
219\end{array}$ & $\begin{array}{l}0.9 \\
1.0 \\
1.1\end{array}$ & $\begin{array}{l}0.8-1.1 \\
0.8-1.3 \\
0.9-1.2\end{array}$ \\
\hline \multirow[t]{2}{*}{$\begin{array}{l}\text { McDonald et al } \\
\text { (52) }\end{array}$} & \multirow[t]{2}{*}{$\begin{array}{l}\text { Case- } \\
\text { referent }\end{array}$} & \multirow[t]{2}{*}{$\begin{array}{l}\text { Self- } \\
\text { reported }\end{array}$} & $\begin{array}{l}\text { Spontaneous } \\
\text { abortion }\end{array}$ & $\begin{array}{l}\text { None } \\
1-6 \mathrm{~h} / \text { week } \\
7-29 \mathrm{~h} / \text { week } \\
>30 \mathrm{~h} / \text { week }\end{array}$ & $\begin{array}{r}356 \\
94 \\
112 \\
75\end{array}$ & $\begin{array}{l}0.9 \\
1.2 \\
1.3 \\
1.1\end{array}$ & $\begin{array}{l}0.8-1.0 \\
1.0-1.5 \\
1.1-1.5 \\
0.9-1.4\end{array}$ \\
\hline & & & $\begin{array}{l}\text { Birth } \\
\text { defect }\end{array}$ & Any & 108 & 0.94 & $0.9-1.0$ \\
\hline $\begin{array}{l}\text { Tikkanen et al } \\
(58)\end{array}$ & $\begin{array}{l}\text { Case- } \\
\text { referent }\end{array}$ & $\begin{array}{l}\text { Estimate by } \\
\text { researchers }\end{array}$ & $\begin{array}{l}\text { Congenital } \\
\text { heart disease }\end{array}$ & $>4 \mathrm{~h} /$ week & 27 & 1.9 & $0.7-5.0$ \\
\hline \multirow[t]{2}{*}{$\begin{array}{l}\text { Goldhaber et al } \\
(50)\end{array}$} & \multirow[t]{2}{*}{$\begin{array}{l}\text { Case- } \\
\text { referent }\end{array}$} & \multirow[t]{2}{*}{$\begin{array}{l}\text { Self- } \\
\text { reported }\end{array}$} & $\begin{array}{l}\text { Spontaneous } \\
\text { abortion }\end{array}$ & $\begin{array}{l}<5 \mathrm{~h} / \text { week } \\
5-20 \mathrm{~h} / \text { week } \\
>20 \mathrm{~h} / \text { week }\end{array}$ & $\begin{array}{l}29 \\
34 \\
52\end{array}$ & $\begin{array}{l}0.9 \\
1.0 \\
1.8\end{array}$ & $\begin{array}{l}0.6-1.4 \\
0.6-1.6 \\
1.2-2.8\end{array}$ \\
\hline & & & $\begin{array}{l}\text { Birth } \\
\text { defect }\end{array}$ & $\begin{array}{l}<5 \mathrm{~h} / \text { week } \\
5-40 \mathrm{~h} / \text { week } \\
>20 \mathrm{~h} / \text { week }\end{array}$ & $\begin{array}{r}8 \\
12 \\
12\end{array}$ & $\begin{array}{l}0.9 \\
1.4 \\
1.4\end{array}$ & $\begin{array}{l}0.4-1.9 \\
0.7-2.7 \\
0.7-2.9\end{array}$ \\
\hline $\begin{array}{l}\text { Bryant \& } \\
\text { Love }(53)^{\mathrm{b}}\end{array}$ & $\begin{array}{l}\text { Case- } \\
\text { referent }\end{array}$ & $\begin{array}{l}\text { Self- } \\
\text { reported }\end{array}$ & $\begin{array}{l}\text { Spontaneous } \\
\text { abortion }\end{array}$ & $\begin{array}{l}<2 \mathrm{~h} / \text { week } \\
2-10 \mathrm{~h} / \text { week } \\
11-20 \mathrm{~h} / \text { week } \\
>21 \mathrm{~h} / \text { week }\end{array}$ & $\begin{array}{l}39 \\
48 \\
15 \\
21\end{array}$ & $\begin{array}{l}0.7 \\
0.8 \\
0.9 \\
1.1\end{array}$ & $\begin{array}{l}0.4-1.1 \\
0.5-1.3 \\
0.4-1.9 \\
0.5-2.1\end{array}$ \\
\hline $\begin{array}{l}\text { Bryant \& } \\
\text { Love }(53)^{\mathrm{b}}\end{array}$ & $\begin{array}{l}\text { Case- } \\
\text { referent }\end{array}$ & $\begin{array}{l}\text { Self- } \\
\text { reported }\end{array}$ & $\begin{array}{l}\text { Spontaneous } \\
\text { abortion }\end{array}$ & $\begin{array}{l}<2 \mathrm{~h} / \text { week } \\
2-10 \mathrm{~h} / \text { week } \\
11-20 \mathrm{~h} / \text { week } \\
>21 \mathrm{~h} / \text { week }\end{array}$ & $\begin{array}{l}41 \\
49 \\
15 \\
22\end{array}$ & $\begin{array}{l}1.5 \\
1.1 \\
1.1 \\
1.1\end{array}$ & $\begin{array}{l}0.9-2.5 \\
0.7-1.6 \\
0.5-2.2 \\
0.6-2.0\end{array}$ \\
\hline
\end{tabular}

a The judgment was based on the mothers' interview descriptions of their jobs. No direct question was asked on the use of video display terminals.

b Two separate reference groups were used in this study.

ances produce magnetic fields of about 0.4 to $1.5 \mu \mathrm{T}$ $(0.3-1.2 \mathrm{~A} / \mathrm{m})$. Fetal loss was significantly more common among users of electric blankets and waterbeds than among nonusers. In addition, seasonal variations in fetal growth and abortion rate were observed in families using waterbeds and electric blankets. The seasonal pattern correlated with changes in temperature. More abortions occurred in the winter months when there was more exposure from bed heating. No seasonal patterns were seen among users of unheated beds. The same researchers have alsu reported seasonal variations in fetal loss for families living in homes with ceiling cable heat $(60)$. Such heating produces a field of about $1 \mu \mathrm{T}$ when the heat is turned on.

The seasonal correlations observed by Wertheimer $\&$ Leeper are not convincing since the expected delay between cause and effect is lacking. If the fetus is affected by low-frequency magnetic fields or any other injurious factor, the development does not stop immediately after the primary effect. It also takes some time before the mother's body reacts to the injured fetus. Thus, if magnetic fields from electric heating were the causal factor, the maximum in fetal loss should have occurred after the maximum in electric heating. No such delay appears in Wertheimer \& Leeper's data. Another disturbing feature in their results is the fact that the abortion rate is correlated with change in temperature rather than with absolute temperature. The maximum in abortions was observed in the autumn and early winter, when the need of heating is increasing, and not simultaneously with the maximum electric heating in the midwinter. Wertheimer \& Leeper's findings are difficult to interpret also because only a small proportion of the eligible couples could be included in the studies and because spontaneous and induced abortions were not differentiated between.

A case-referent study was conducted in Finland to investigate the possible association of early pregnancy field exposure (61). Eighty-nine cases and 102 referents were obtained from the data of an earlier study aimed at investigating the incidence of early pregnancy loss in a group of women attempting to get pregnant. The exposure to magnetic fields was determined by 
measurements in residences. For analysis, the measured magnetic field values were divided to three categories. Exposure to the highest category $(>0.5 \mathrm{~A} / \mathrm{m})$ was more common among the cases than among the referents. In an analysis based on the fields measured at the front door, the crude odds ratios were 5.1 (95\% CI 1.0-25) for the highest exposure category and 1.09 (95\% Cl $0.6-2.0$ ) for the $0.1-0.49 \mathrm{~A} / \mathrm{m}$ category. Adjustment for maternal age, smoking, and type of residence did not materially alter the results. The trend in the odds ratios was significant at $\mathbf{P}=0.04$.

An increased proportion of spontaneous abortions has been reported for Finnish women employed in the electronics industry (62). The increase was highest in radio and television manufacturing. The authors suggested that exposure to solder fumes could explain the increased risk. An alternative explanation could be exposure to low-frequency magnetic fields, since soldering equipment produce fields clearly stronger than the background level of offices and residences. Field strengths from 0.14 to $4.8 \mathrm{~A} / \mathrm{m}(0.18-6 \mu \mathrm{T})$ have been measured at the worker's position in two electronics factories (Juutilainen et al, unpublished measurements).

Only little epidemiologic evidence is available on the possible association of exposure to low-frequency magnetic fields and pregnancy outcome. It seems probable that video display terminals are safe to use during pregnancy. A slight excess risk for fetal loss and birth defects with a high level of use of video display terminals cannot be ruled out, however. If the risk is real, the causal factor may be exposure to low-frequency magnetic fields, as well as, for example, ergonomic factors or stress. There is some indication of increased risks among women exposed to other magnetic field sources. Studies on heavily exposed workers are lacking, however.

\section{Discussion}

Some people are exposed to field strengths comparable with those used in the experimental studies reporting effects on embryonal development. Effects on human health are thus possible if the reported effects can be confirmed to occur also in humans. At $50 \mathrm{~Hz}$, the effects on chick embryos seem to occur above a minimum field strength of $1 \mathrm{~A} / \mathrm{m}(1.3 \mu \mathrm{T})$. At higher frequencies some researchers have reported effects at field strengths below $1 \mathrm{~A} / \mathrm{m}$. Effects on mammals have been reported only at or above $10 \mathrm{~A} / \mathrm{m}$, but there are too few data on the dependence of the effects on field strength. Field strengths between 1 and $100 \mathrm{~A} / \mathrm{m}$ are found at several workplaces, and $50-\mathrm{Hz}$ fields up to about $10 \mathrm{~A} / \mathrm{m}$ have been measured in some exceptional cases in residences $(63,64)$. The typical level in homes is below $0.1 \mathrm{~A} / \mathrm{m}(64,65)$.

In epidemiologic studies indications of possible increased risks have been found at field strengths of
$0.4-1.5 \mu \mathrm{T}$ (59), $1 \mu \mathrm{T}(60)$, or above $0.5 \mathrm{~A} / \mathrm{m}$ $(0.6 \mu \mathrm{T})(61)$. These values agree fairly well with the experimental data suggesting a threshold of $1 \mathrm{~A} / \mathrm{m}$ for the effects on chick embryos (20). The exposure of operators of video display terminals is usually lower $(0.1-0.3 \mathrm{~A} / \mathrm{m})$, but direct comparison to $50-\mathrm{Hz}$ field strengths may be misleading because of the differences in waveform and frequency.

Present knowledge of the interaction mechanisms between magnetic fields and living organisms does not explain the reported effects of low-frequency magnetic fields on embryonal development. The field strengths used were so low that interaction based on induced currents is unlikely (66). Several hypothetical mechanisms have been reported to explain the effects of weak fields $(27,67-71)$. These hypotheses have not been confirmed experimentally, although some observations seem to agree with Liboff's (27) "cyclotron resonance theory"' $(72,73)$.

Many in vitro experiments suggest that relatively weak low-frequency magnetic fields affect cell metabolism, proliferation, and growth (74-77). Such effects could theoretically be responsible for disturbances in embryonal development.

\section{Concluding remarks}

It appears that low-frequency magnetic fields have adverse effects on chick embryo development. There are variations in the results, but the combined data suggest that there is a real effect modulated by some unknown biological or environmental variables. Chick embryos in the early stages of development are affected. As the interaction mechanism between low-frequency magnetic fields and chick embryos is not known, it is not yet possible to conclude whether similar effects could be expected in humans.

The results of the experiments with mammals are inconsistent. There is more evidence of effects on mice than on rats, and the data suggest that the risk of fetal loss might be increased rather than that of malformations. An increase in fetal loss would be consistent with effects during the early stages of development.

The results of the epidemiologic studies do not provide much evidence for an association between adverse pregnancy outcomes and the use of video display terminals. Other sources of low-frequency magnetic fields have been addressed only in a few studies.

If a risk of fetal injury exists, it is likely to be small. Experimental studies with mammals suggest that, if there are effects, only a small portion of the fetuses is affected. Relative risks from less than 1 to 5 have been reported in the epidemiologic studies, but there is little information on exposure levels and the proportion of really exposed persons in the populations studied.

There is an apparent need for further investigation. It is not yet possible to conclude whether exposure to low-frequency magnetic fields affects human prenatal 
development. The available data, however, give some hints of how to direct future research in this area.

The possible human reproductive hazards should be further investigated by epidemiologic studies and teratological experiments with mammals. In addition, further experiments are necessary to reveal the biophysical and biochemical mechanisms of the effects observed in chick embryos. Since effects have been reported in CBA mice, it would be very useful if the same strain of mice could be used in further teratological investigations by independent researchers. To reveal the effects on early development suggested by some experimental studies, epidemiologic investigations should focus on fetal loss rather than on birth defects.

\section{References}

1. World Health Organization (WHO). Extremely low frequency (ELF) fields. Geneva: WHO, 1984. (Environmental health criteria; no 35 .)

2. World Health Organization (WHO). Magnetic fields Geneva: WHO, 1987. (Environmental health criteria; no 69.)

3. Aldrich TE, Easterly CE. Electromagnetic fields and public health. Environ Health Perspect 1987;75:15971.

4. Kavet RI, Banks RS. Emerging issues in extremely-lowfrequency electric and magnetic field health research. Environ Res 1986;39:386-404.

5. Coleman M, Beral V. A review of epidemiological studies of the health effects of living near or working with electricity generation and transmission equipment. Int J Epidemiol 1988;17:1-13.

6. Savitz DA, Calle EE. Leukemia and occupational exposure to electromagnetic fields: review of epidemiologic surveys. J Occup Med 1987;29:47-51.

7. Sheikh K. Exposure to electromagnetic fields and the risk of leukemia. Arch Environ Health 1986;41:56 - 63.

8. Brown HD, Chattopadhyay SK. Electromagnetic-field exposure and cancer. Cancer Biochem Biophys 1988;9: 295-342.

9. Ahlbom A. A review of the epidemiologic literature on magnetic fields and cancer. Scand $J$ Work Environ Health 1988;14:337-43.

10. Delgado JMR, Leal J, Monteagudo JL, Garcia Gracia M. Embryological changes induced by weak, extremely low frequency electromagnetic fields. J Anat 1982;134: $533-51$.

11. Ubeda A, Leal J, Trillo MA, Jimenez MA, Delgado JMR. Pulse shape of magnetic fields influences chick embryogenesis. J Anat 1983;137:513-36.

12. Ubeda A, Leal J, Trillo MA, Jimenez MA, Delgado JMR. Authors' correction to data. J Anat 1985;140: 721

13. Ingenjörsvetenskapsakademien (IVA). Biologiska effekter av kraftfrekventa elektriska och magnetiska fält [Biological effects of power frequency electric and magnetic fields]. Stockholm: IVA, 1987. (IVA-rapport 323)

14. Ubeda A, Trillo MA, Leal J. Magnetic field effects on embryonic development: influence of the organism's orientation. IRCS Med Sci 1987;15:531-2.

15. Leal J, Shamsaifar K, Trillo MA, Ubeda A, Abraira V, Chacon L. Embryonic development and weak changes of the geomagnetic field. J Bioelectricity 1989;7:141153.

16. Martin AH. Magnetic fields and time dependent effects on development. Bioelectromagnetics 1988;9:393-6.

17. Juutilainen J, Harri M, Saali K, Lahtinen T. Effects of
$100-\mathrm{Hz}$ magnetic fields with various waveforms on the development of chick embryos. Radiat Environ Biophys 1986;25:65-74.

18. Juutilainen J, Saali K. Development of chick embryos in $1 \mathrm{~Hz}$ to $100 \mathrm{kHz}$ magnetic fields. Radiat Environ Biophys 1986;25:135-40.

19. Juutilainen J. Effects of low frequency magnetic fields on chick embryos: dependence on incubation temperature and storage of the eggs. Z Naturforsch $1986 ; 41 \mathrm{c}$ : $1111-5$.

20. Juutilainen J, Läärä E, Saali K. Relationship between field strength and abnormal development in chick embryos exposed to $50-\mathrm{Hz}$ magnetic fields. Int J Radiat Biol 1987;52:787-793.

21. Maffeo S, Miller MW, Carstensen EL. Lack of effect of weak low frequency electromagnetic fields on chick embryogenesis. J Anat 1984;139:613-8.

22. Maffeo S, Brayman AA, Miller MW, Carstensen EL, Ciaravino V, Cox C. Weak low frequency electromagnetic fields and chick embryogenesis: failure to reproduce findings. J Anat 1988;157:101-4.

23. Sandström M, Hansson Mild K, Lovtrup S. Effects of weak pulsed magnetic fields on chick embryogenesis. In: Knave B, Wideback P-G, ed. Work With display units. Amsterdam: Elsevier Science Publishers, 1987:135-40.

24. Fargeix N, Henou C, Cabanes J, Delost P, Portet R. Étude du développement embryonnaire précoce sur l'oeuf d'Oiseau soumis à un champ magnetique. Soc Biol 1988; 182:235-43.

25. Sisken BF, Fowler I, Mayaud C, Ryaby JP, Pilla AA. Pulsed electromagnetic fields and normal chick development. J Bioelectricity 1986;5:25-34.

26. Berman E, Chacon L, House D, et al. Development of chicken embryos in a pulsed magnetic field. Bioelectromagnetics 1990;11:169-87.

27. Liboff AR. Geomagnetic cyclotron resonance in living cells. J Biol Physics 1985;13:99-102.

28. Cameron IL, Hunter KE, Winters WD. Retardation of embryogenesis by extremely low frequency $60 \mathrm{~Hz}$ electromagnetic fields. Physiol Chem Phys Med NMR 1985; 17:135-8.

29. Bardasano JL, Meyer AJ, Picazo L. Pineal cells with multipolar spindles in chicken embryos exposed to magnetic fields - first trials. Z Mikrosk Anat Forsch 1986; 100:85-92.

30. Falugi C, Grattarola M, Prestipino G. Effects of lowintensity pulsed electromagnetic fields on the early development of sea urchins. Biophys J 1987;51:999-1003.

31. Zimmerman S, Zimmerman AM, Winters WD, Cameron IL. Influence of $60-\mathrm{Hz}$ magnetic fields on sea urchin development. Bioelectromagnetics 1990;11:37-45.

32. Ueno S, Kitahara T, Harada K, Shiokawa L. The effects of ELF magnetic and electric fields on the embryonal development of frogs. In: Bioelectromagnetics Society. Proceedings of the 7th annual meeting, June 16-20 1985. San Francisco: Bioelectromagnetics Society, 1985:12.

33. Ramirez E, Monteagudo JL, Garcia Gracia M, Delgado JMR. Oviposition and development of Drosophila modified by magnetic fields. Bioelectromagnetics 1983;4: $315-26$.

34. Zecca L, Ferrario P, Dal Conte G. Toxicological and teratological studies in rats after exposure to pulsed magnetic fields. Bioelectrochem Bioenerg 1985;14:63-9.

35. Rivas L, Rius C, Tello I, Oroza MA. Effects of chronic exposure to weak electromagnetic fields in mice. IRCS Med Sci 1985;13:661-662.

36. Tribukait B, Cekan E, Paulsson LE. Effects of pulsed magnetic fields on embryonic development in mice. In: Knave, B Wideback P-G, ed. Work with display units. Amsterdam: Elsevier Science Publishers, 1987:129-34.

37. Frölen H, Svedenstål B-M. Pulserande magnetfälts inverkan på fosterutvecklingen hos möss: kompletterande och utökad studie till tidigare rapporterad undersökning 
[The influence of pulsing magnetic fields on fetal development in mice]. Uppsala: Sveriges Lantbruksuniversitet, Enheten för Experimentell Patologi och Riskforskning, Institutionen för Patologi, 1989. (Projekt SSI 493.88.)

38. Svedenstål B-M, Frölen H. Effects of pulsed magnetic fields on the developing mouse embryo. Bioelectromagnetics (in press).

39. Stuchly MA, Ruddick J, Villeneuve D, et al. Teratological assessment of exposure to time-varying magnetic field. Teratology 1988;38:461-6.

40. Huuskonen H, Juutilainen J, Komulainen H. Effects of low frequency magnetic fields on fetal development in rats. Bioelectromagnetics (in press).

41. Rommereim DN, Rommereim RL, Buschbom RL, Anderson LE. Developmental toxicity study in rats exposed to $60 \mathrm{~Hz}$ horizontal magnetic fields. In: Bioelectromagnetics Society. Twelfth annual meeting, June 1990. San Antonio: Bioelectromagnetics Society, 1990:20-1.

42. Walsh M, Agnew D, Wiley M, et al. Experimental research assessing biological effects of exposure to VLF magnetic fields: the University of Toronto study as a model. Paper presented at the Second International Scientific Conference, Work with Display Units. Montreal, 1989.

43. McGivern RF, Sokol RZ, Adey WR. Prenatal exposure to a low-frequency electromagnetic field demasculinizes adult scent marking behavior and increases accessory sex organ weights in rats. Teratology 1990;41:1-8.

44. Algers B, Hultgren J. Effects of long-term exposure to a $400-\mathrm{kV}, 50-\mathrm{Hz}$ transmission line on estrous, fertility and diurnal rhythm in cows. Skara: Sveriges Lantbruksuniversitet, Veterinärmedicinska fakulteten, 1986. (Rapport 15.)

45. Schardein JL. Principles of teratogenesis applicable to human exposure to drugs and chemicals. In: Schardein JL, ed. Chemically induced birth defects. New York and Basel: Marcel Dekker, Inc, 1985:1-46. (Drug and chemical toxicology; vol 2.)

46. Haseman JK, Hogan MD. Selection of the experimental unit in teratology studies. Teratology $1976 ; 12: 165-$ 72.

47. Bergqvist UOV. Video display terminals and health: a technical and medical appraisal of the state of the art. Scand J Work Environ Health 1984;10(suppl 2):87 p.

48. Juutilainen J, Saali K. Measurements of extremely lowfrequency magnetic fields around video display terminals. Scand J Work Environ Health 1986;12:609-13.

49. Jokela K, Aaltonen J, Lukkarinen A. Measurements of electro-magnetic emissions from video display terminals at the frequency range from $30 \mathrm{~Hz}$ to $1 \mathrm{MHz}$. Health Phys 1989;57:79-88.

50. Goldhaber MK, Polen MR, Hiatt AR. The risk of miscarriage and birth defects among women who use visual display terminals during pregnancy. Am J Ind Med 1988; 13:695-706.

51. Ericson A, Källen B. An epidemiological study of work with video screens and pregnancy outcome: II. a casecontrol study. Am J Ind Med 1986;9:459-75.

52. McDonald AD, Cherry NM, Delorme C, McDonald JC Visual display units and pregnancy: evidence from the Montreal survey. J Occup Med 1986;28:1226-31.

53. Bryant HE, Love EJ. Video display terminal use and spontaneous abortion risk. Int J Epidemiol 1989;18: 132-8.

54. Ericson A, Källen B. An epidemiological study of work with video screens and pregnancy outcome: I. a registry study. Am J Ind Med 1986;9:447-57.

55. Kurppa K, Holmberg PC, Rantala K, Nurminen T, Saxén L. Birth defects and exposure to video display terminals during pregnancy: a Finnish case-referent study. Scand J Work Environ Health 1985;11:353-6.

56. Bràndt LPA, Nielsen CV. Congenital malformations among children of women working with video display terminals. Scand J Work Environ Health 1990;16:32933.

57. Nielsen CV, Brandt LPA. Spontaneous abortion among women using video display terminals. Scand J Work Environ Health 1990;16:323-8.

58. Tikkanen J, Heinonen OP, Kurppa K, Rantala K. Äidin alkuraskauden aikainen näyttöpäätetyö ja lapsen synnynnäiset sydänviat [Mother's work with video display terminals during early pregnancy and the baby's congenital heart disease]. Sosiaalilää Aikak 1987;24:311-6.

59. Wertheimer N, Leeper E. Possible effects of electric blankets and heated waterbeds on fetal development. Bioelectromagnetics 1986;7:13-22.

60. Wertheimer N, Leeper E. Fetal loss associated with two seasonal sources of electromagnetic field exposure. Am J Epidemiol 1989;129:220 - 4.

61. Matilainen P, Juutilainen J, Saarikoski S, Läärä E, Suonio S. Early pregnancy loss and exposure to $50-\mathrm{Hz}$ magnetic fields. In: Huttunen P, Juutilainen J, Mustonen $\mathrm{M}$, Olkkonen $\mathrm{H}$, ed. Proceedings of the URSI/IEEE XVI national convention on radio science, November 1990. Kuopio (Finland): University of Kuopio, 1990:E215. (Publications of the University of Kuopio, natural sciences, original reports 1990;9.)

62. Hemminki K, Niemi ML, Koskinen K, Vainio H. Spontaneous abortions among women employed in the metal industry in Finland. Int Arch Occup Environ Health 1980;47:53-60.

63. Krause N. Exposure of people to static and time variable magnetic fields in technology, medicine, research and public life; dosimetric aspects. In: Bernhardt J, ed. Biological effects of static and extremely low frequency magnetic fields. München: MMV Medizin Verlag, 1986:57-71. (bga-Schriften 3/1986.)

64. Juutilainen J, Saali K, Eskelinen J, Matilainen P, Leino nen A-L. Measurements of $50-\mathrm{Hz}$ magnetic fields in Finnish homes. Helsinki: Imatran Voima Oy, 1989. (IVO Research Reports IVO-A-02/89.)

65. Eriksson A, Hansson Mild K, Lindh T, Paulsson LE, Waltré M, Östman U. $50 \mathrm{~Hz}$ magnetfält i bostäder [50-Hz magnetic fields in residences]. Umeå: Arbetarskyddsstyrelsen, 1987. (Undersökningsrapport 1987:6.)

66. Bernhardt $J$. The direct influence of electromagnetic fields on nerve and muscle cells on man within the frequency range of $1 \mathrm{~Hz}$ to $30 \mathrm{MHz}$. Radiat Environ Biophys $1979 ; 16: 309-23$.

67. Chiabrera A, Grattarola M, Viviani R. Interaction between electromagnetic fields and cells: microelectrophoretic effect on ligands and surface receptors. Bioelectromagnetics 1984;5:173-91.

68. Chiabrera A, Bianco B. The role of the magnetic field in the EM interaction with ligand binding. In: Blank $M$, Findl E, ed. Mechanistic approaches to interactions of electric and magnetic fields with living systems. New York, NY: Plenum Press, 1987:79-95.

69. Findl E. Membrane transduction of low energy level fields and the $\mathrm{Ca}++$ hypothesis. In: Blank M, Findl $\mathrm{E}$, ed. Mechanistic approaches to interactions of electric and electromagnetic fields with living systems. New York, NY: Plenum Press, 1987:15-38.

70. Grattarola M, Caratozzolo F, Chiabrera A. Interaction of ELF electromagnetic fields with cell membrane receptors. In: Grandolfo M, Michaelson SM, Rindi A, ed. Biological effects and dosimetry of static and ELF electromagnetic fields. New York, NY: Plenum Press 1985: 273-93.

71. Polk C. Modification of charge distribution at boundaries between electrically dissimilar media. In: Blank M, Findl E, ed. Mechanistic approaches to interactions of electric and electromagnetic fields with living systems. New York, NY: Plenum Press, 1987:63-77.

72. Smith SD, McLeod BR, Liboff AR, Cooksey K. Calcium cyclotron resonance and diatom mobility. Bioelec- 
tromagnetics $1987 ; 8: 215-27$.

73. Liboff AR, Rozek RJ, Sherman ML, McLeod BR, Smith SD. Ca2 +-45 cyclotron resonance in human lymphocytes. J Bioelectricity 1987;6:13-22.

74. Liboff AR, Williams T, Strong DM, Wistar R. Timevarying magnetic fields: effect on DNA synthesis. Science 1984;223:818-20.

75. Phillips JL, Winters WD, Rutledge $L$. In vitro exposure to electromagnetic fields: changes in tumour cell properties. Int J Radiat Biol 1986;49:463-9.
76. Akamine T, Muramatsu H, Hamada H, Sakou T. Effects of pulsed electromagnetic fields on growth and differentiation of embryonal carcinoma cells. J Cell Physiol 1985; 124:247-54.

77. Aarholt E, Flinn EA, Smith CW. Effects of low-frequency magnetic fields in bacteria growth rate. Phys Med Biol 1981;26:613-21.

Received for publication: 23 October 1990 